\title{
Analisis Tegangan Sekat Memanjang Tanker akibat Beban Sloshing menggunakan Metode Elemen Hingga
}

\author{
Ardan Nagra Coutsar, Dony Setyawan \\ Departemen Teknik Perkapalan, Fakultas Teknologi Kelautan, \\ Institut Teknologi Sepuluh Nopember (ITS) 60111 Indonesia \\ e-mail:ardan15@mhs.na.its.ac.id, dony@na.its.ac.id
}

\begin{abstract}
Abstrak-Sloshing merupakan pergerakan fluida secara bebas dalam sebuah wadah. Sloshing terjadi akibat pergerakan dari kapal itu sendiri. Beban atau gaya yang terjadi akibat muatan cair yang mengalami sloshing perlu dianalisis dan dianggap penting, terutama pada kapal-kapal yang memiliki ruang muat besar seperti super tanker atau kapal LNG berukuran besar. Kemungkinan sloshing yang terjadi pada ruang muat tersebut akan lebih besar apabila terjadi resonansi dengan gerakan kapal. Tegangan yang terjadi pada tangki dihitung dengan menggunakan pendekatan numerik untuk mengetahui respon hidrodinamis yang terjadi akibat muatan cair dalam tangki ruang muat. Pengaruh sloshing yang terjadi pada tegangan sekat memanjang tangki ruang muat didapatkan dengan perhitungan numerik. Hasil yang didapat antara lain tegangan maksimum yang terjadi pada saat ketinggian cairan terisi $10 \%$ adalah sebesar $15.962 \mathrm{Mpa}$, saat ketinggian cairan terisi $30 \%$ adalah sebesar 30.852 Mpa, saat cairan terisi $50 \%$ adalah sebesar 47.049 Mpa, serta saat cairan terisi $80 \%$ adalah sebesar 50.968 Mpa. Sehingga terdapat kenaikan tegangan yang cukup signifikan saat kondisi ruang muat terisi dengan ketinggian rendah. Kenaikan tegangan yang terjadi hingga mencapai $93.28 \%$ saat ruang muat terisi dari $10 \%$ ke $30 \%$.
\end{abstract}

Kata Kunci - computational fluid dynamic, dynamic mesh, finite element method, sloshing, stress.

\section{PENDAHULUAN}

$\mathrm{P}$ ENGOPERASIAN kapal tanker meningkat seiring dengan bertambahnya jumlah kapal dengan berbagai variasi tangki muatan cair. Banyak permasalahan struktur tangki yang dicatat terkait dengan beban sloshing yang terjadi dalam ruang muat [1]. Permasalahan tersebut berkaitan dengan sloshing yang terjadi pada tangki-tangki membran. Misalnya saja Kapal Polar Alaska yang mengalami kerusakan tangki pada saat ruang muat kapal tersebut terisi sekitar 15$20 \%$.

Salah satu komponen dalam ruang muat muat kapal yang dikenai beban sloshing adalah longitudinal bulkhead. Bulkhead atau sekat adalah salah satu bagian kapal yang membagi satu kompartemen satu dengan kompartemen yang lainnya [2]. Bulkhead pada kapal terbagi menjadi dua jenis diantaranya adalah transverse bulkhead dan longitudinal bulkhead. Longitudinal bulkhead merupakan sekat memanjang kapal yang sering dikenai beban sloshing akibat gerakan rolling kapal itu sendiri. Pendekatan analisis tidak dapat dilakukan untuk memperkirakan gaya yang timbul akibat beban sloshing disekitar frekuensi resonansi, terutama pada saat resonansi yang terjadi dengan amplitudo eksitasi yang besar.

Teori linier sloshing hanya berlaku untuk amplitudo dan frekuensi eksitasi rendah, selain itu teori tersebut hanya dapat digunakan untuk memperkirakan respon pada area resonansi saja. Sedangkan untuk teori non-linier sloshing dapat digunakan untuk memperkirakan gaya berupa tekanan dinamis akibat beban sloshing pada konstruksi tangki, tetapi hal tersebut hanya berlaku pada amplitudo eksitasi kecil serta tidak dapat digunakan untuk bentuk tangki secara umum atau untuk memperhitungkan tekanan impact pada tangki [3]. Oleh karena itu untuk memperhitungkan tegangan yang terjadi pada tangki digunakan pendekatan numerik untuk mengetahui respon hidrodinamis yang terjadi akibat muatan cair dalam tangki ruang muat.

\section{TINJAUAN PUSTAKA}

\section{A. Gerakan Rolling}

Rolling merupakan gerakan kapal yang terjadi pada saat kapal mengelilingi sumbu x. Ketika kapal rolling bagian sisi kanan kapal bergerak kesebelah sisi kiri kapal yang terulang secara bergantian [4].

\section{B. Dinamika Sloshing}

Gelombang pada sloshing akan terbentuk dengan hasil yang berbeda antara satu sama lain. Hal ini dipengaruhi oleh kedalaman cairan dan frekuensi osilasi. Gelombang yang mungkin terjadi diantaranya adalah standing wave, traveling wave, hydaulic jump, serta kombinasi dari ketiga gelombang tersebut. Standing wave akan terbentuk saat ketinggian cairan yang dangkal dan berosilasi pada frekuensi yang jauh lebih rendah daripada frekuensi resonansi. Standing wave akan berubah menjadi traveling wave dengan panjang gelombang yang sangat pendek saat frekuensi yang terjadi meningkat. Sedangkan tipe gelombang hydraulic jump akan terjadi ketika terjadi gangguan kecil dan muncul diatas rentang frekuensi didekat frekuensi resonansi. Apabila frekuensi meningkat lebih besar maka akan terjadi solitare wave [5].

Terdapat beberapa metode dalam menentukan pergerakan cairan yang disebut dengan sloshing ini. Salah satu metode yang digunakan adalah dengan menggunakan metode quasistatis. Metode ini digunakan untuk menyederhanakan permukaan bebas cairan dengan menggambaran sebagai garis lurus yang berhubungan dengan pergerakan rolling dan percepatan lateral yang dihasilkan. Kelemahan dari metode ini adalah hanya dapat digunakan saat fluida dalam keadaan steady state [6].

\section{Computational Fluid Dynamics}

Penggunaan Computational Fluid dynamics sudah sangat luas [7]. CFD pada saat ini digunakan sebagai alat untuk mendapatkan solusi dalam dunia engineering. Dengan menggunakan metode ini dapat menghasilkan prediksi 
kualitatif dengan menggunakan beberapa metode diantaranya adalah:

a. Model Matematik (PDE)

b. Metode numeric (diskritasi dan teknik solusi)

c. Perangat lunak

Computational fluid dynamics digunakan oleh ilmuwan sebagai 'eksperimen numerik' dalam sebuah 'virtual laboratorium'. CFD dapat mensimulasikan sebuah fenomena yang terjadi pada fluida.

\section{Metode Elemen Hingga}

Persoalan perancangan dapat diselesaikan dengan cara matematis dan numeris [8]. Penyelesaiannya akan sulit menggunakan cara matematis untuk benda-benda yang mempunyai bentuk yang tidak teratur (elemen isoparametrik), sehingga perlu digunakan cara numerik. Cara numerik dalam perkembangannya disebut sebagai metode elemen hingga (Finite Elements Method).

\section{METODOLOGI}

\section{A. Metode}

Metode yang digunakan adalah berbasis analisis beban sloshing dengan menggunakan pendekatan computational fluids dynamics yang selanjutnya menjadi pembebanan pada konstruksi sekat memanjang tanker. Kemudian dilakukan variasi ketinggian cairan pada ruang muat untuk dianalisis tegangan yang terjadi pada sekat tersebut.

\section{B. Pengumpulan Data}

Kapal yang digunakan sebagai bahan penelitian ini adalah kapal Oil Tanker 17500 LTDW. Data yang digunakan diantaranya adalah data ukuran utama dari kapal.

Tabel 1.

Data kapal tanker yang digunakan

\begin{tabular}{ccc}
\hline \hline Deskripsi & Ukuran & Satuan \\
\hline Displacement $(\Delta)$ & 17500 & ton \\
Length Overall (LOA) & 157.50 & $\mathrm{~m}$ \\
Length Construction (LPP) & 149.50 & $\mathrm{~m}$ \\
Breadth Moulded (B) & 27.70 & $\mathrm{~m}$ \\
Depth Moulded (H) & 12.00 & $\mathrm{~m}$ \\
Draft (T) & 7.00 & $\mathrm{~m}$ \\
Service Speed (Vs) & 13 & $\mathrm{knots}$ \\
\hline \hline
\end{tabular}

Data lain yang diperlukan adalah data ruang muat dari tanker. Data ini terdapat pada midship kapal tersebut.

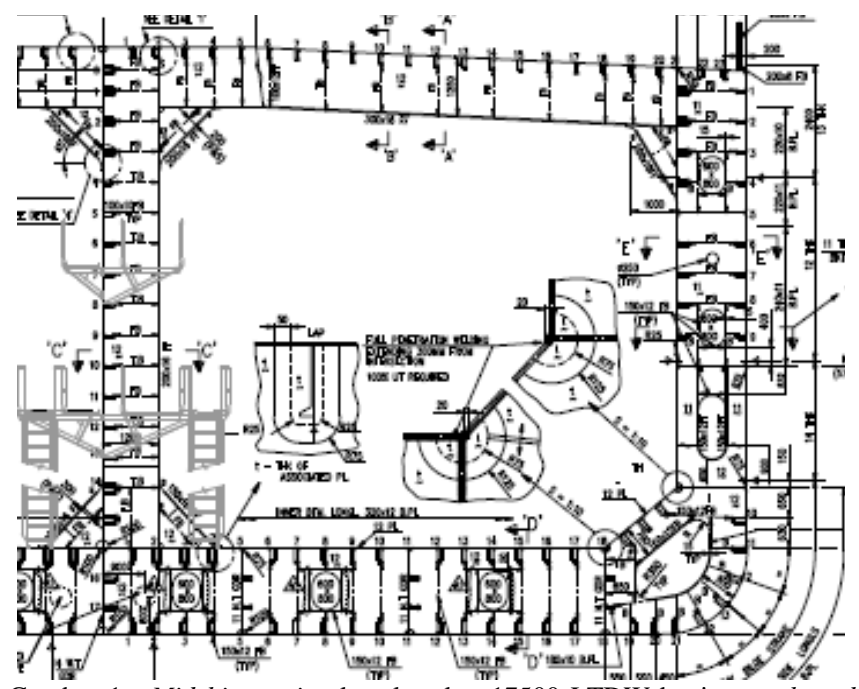

Gambar 1. Midship section kapal tanker 17500 LTDW bagian starboard pada cargo hold 3 yang digunakan sebagai pemodelan.
Dibutuhkan data contruction profile untuk dapat memodelkan sekat dari ruang muat.

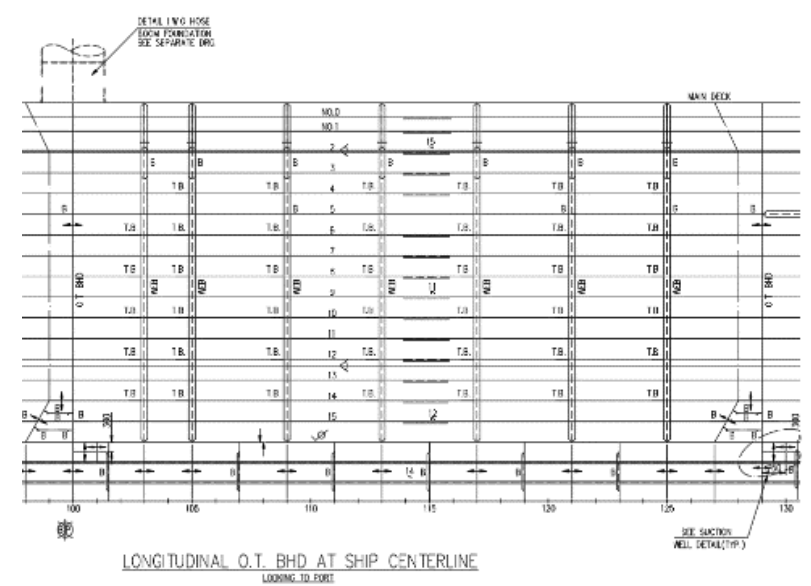

Gambar 2. Construction profile sekat memanjang tanker 17500 LTDW pada frame 100 sampai 129 yang digunakan sebagai model sekat.

\section{Meshing Domain Fluida}

Meshing perlu dilakukan pada domain starboard dan portside dari ruang muat.

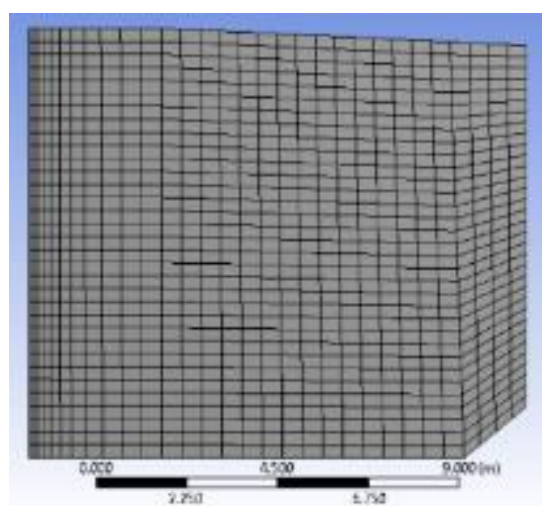

Gambar 3. Pembuatan model domain fluida bagian starboard ruang muat dari kapal tanker. Refinement dilakukan pada bagian domain sekatnya.

Pembuatan domain fluida juga dilakukan pada bagian portside ruang muat dari kapal tanker.

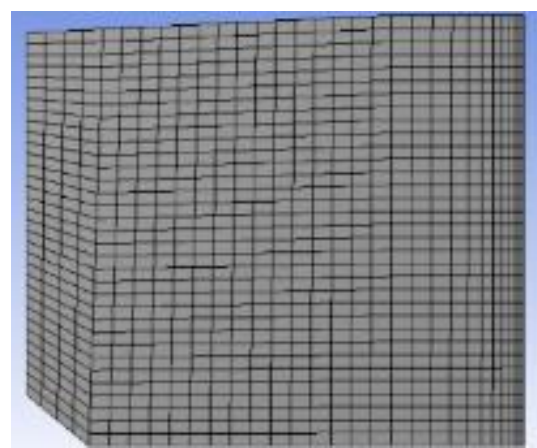

Gambar 4. Pembuatan model domain fluida bagian portside ruang muat dari kapal tanker. Refinement dilakukan pada bagian domain sekatnya.

\section{Grid Convergence Study Model Fluida}

Perlu dilakukan grid convergence study agar didapatkan analisis yang memuaskan. Grid Convergence Study perlu dilakukan walapun proses simulasi dari computational fluid dynamics merupakan berbasis iterasi. Hal ini dilakukan karena konvergensi yang dimaksud adalah akibat pengaruh dari grid yang dibuat.

Tahap ini juga dilakukan pengecekan error yang diakibatkan oleh diskritisasi model dengan menggunakan Rhicardon's Extrapolation [9]. 


$$
f_{\text {true }}=f_{2}+\frac{\left(f_{1}-f_{2}\right) r^{p}}{r^{p}-1}
$$

$f_{\text {true }}$ adalah final true solution, $f_{1}$ nilai dari solusi grid pertama, $f_{2}$ nilai dari solusi grid kedua, $f_{3}$ nilai dari solusi grid ketiga, $r$ adalah rasio refinement

$$
r_{\text {effective }}=\left(\frac{N_{1}}{N_{2}}\right)^{\frac{1}{D}}
$$

$r_{\text {effective }}$ adalah keefektifan refinement, $N_{1}$ jumlah elemen pertama, $N_{2}$ jumlah elemen kedua, $D$ adalah jenis dimensi analisis.

$$
p=\frac{\ln \left(\frac{f 3-f 2}{f 2-f 1}\right)}{\ln (r)}
$$

$\mathrm{p}$ adalah ordo dari konvergensi.

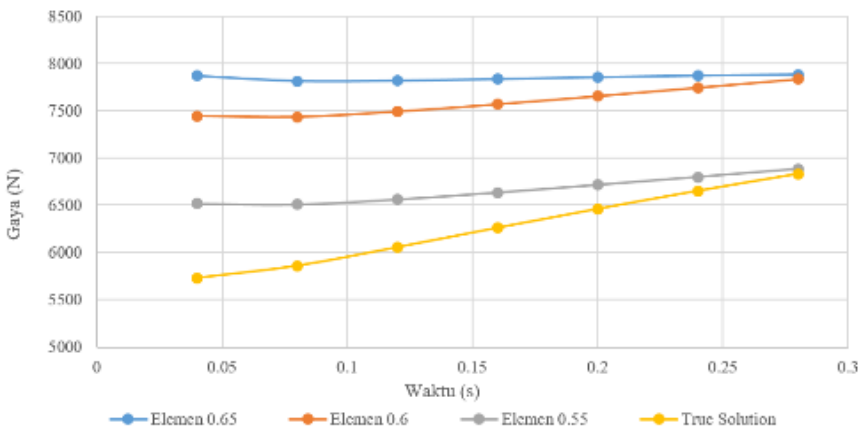

Gambar 5. Dasar pemilihan elemen dengan ukuran 0.55 meter sebagai simulasi sloshing dibandingkan dengan true solution, ukuran 0.6 meter dan ukuran 0.65 meter

\section{E. Meshing Struktur Sekat}

Meshing adalah proses mendeskitkan model geometri menjadi elemen-elemen hingga.

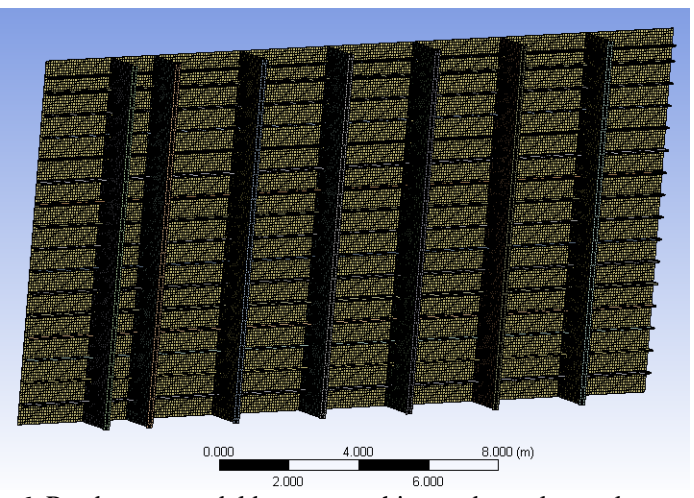

Gambar 6. Pembuatan model beserta meshing pada struktur sekat

\section{F. Grid Convergence Study Model Struktur}

Grid convergence study dilakukan untuk mendapatkan analisis yang akurat. Tahap ini dilakukan untuk membandingkan hasil yang didapatkan dari proses simulasi dengan melihat apakah hasil akan berpengaruh terhadap perubahan mesh yang dilakukan.

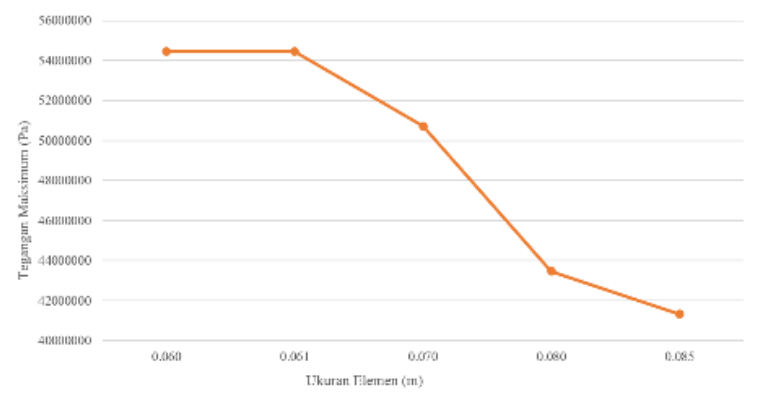

Gambar 5. Dasar pemilihan elemen dengan ukuran 0.061 meter sebagai model struktur sekat dibandingkan dengan ukuran 0.060 meter, 0.070, 0.080 meter serta 0.085 meter.

\section{G. Kondisi Batas pada Model Struktur}

Kondisi batas yang digunakan adalah menggunakan fixed support pada bagian setiap ujung dari sekat termasuk pada profile bulb dan juga pada bagian transverse dari sekat.

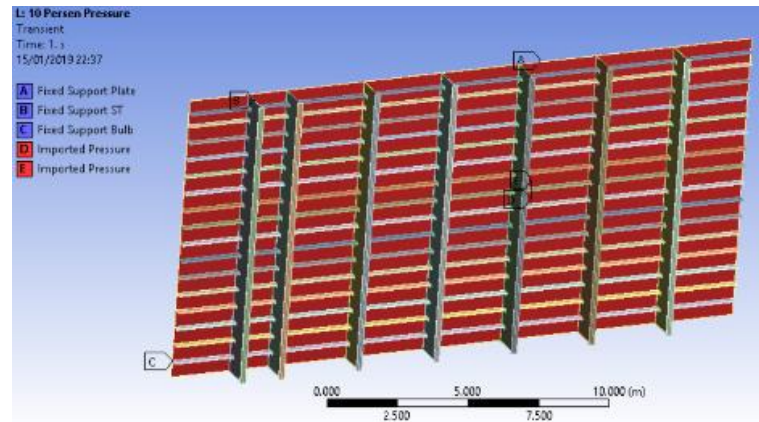

Gambar 5. Kondisi batas pada model struktur beserta pembebanan yang didapatkan dari perhitungan computational fluid dynamics berupa imported pressure. Digunakan simulasi menggunakan Fluid Structure Interaction.

Tabel 2.

Kondisi batas pada pemodelan struktur sekat

\begin{tabular}{ccl}
\hline \hline Bagian & Konstruksi & Kondisi batas \\
\hline A & Ujung, pangkal, sisi atas dan bawah pelat & fixed support \\
B & Ujung dan pangkal transverse & fixed support \\
C & Ujung dan pangkal profil bulb & fixed support \\
\hline \hline
\end{tabular}

H. Diagram Alir

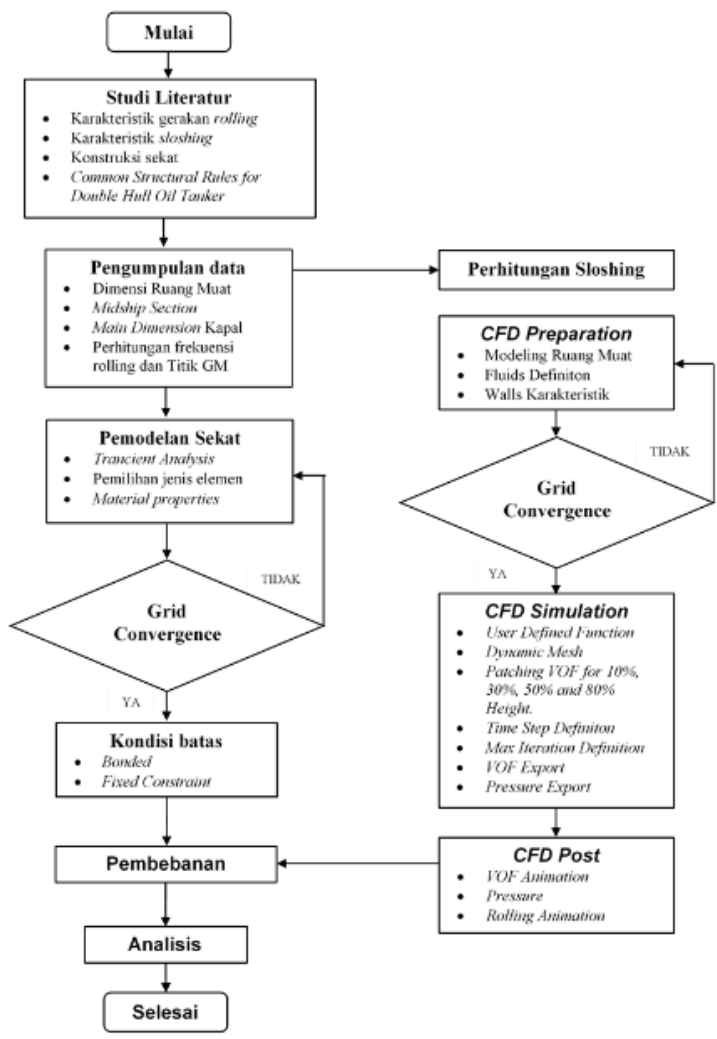

Gambar 6. Diagram alir pengerjaan penelitian.

Perhitungan beban sloshing menggunakan simulasi computational fluid dynamics sedangkan untuk analisis struktur digunakan pendekatan finite element method.

\section{ANALISIS DAN PEMBAHASAN}

\section{A. Periode Rolling}

Periode rolling dari kapal didapatkan dengan menggunakan pendekatan yang ditulis dalam common 
structural rules yaitu sebesar 9.914 detik sehingga frekuensi rolling yang didapatkan sebesar $0.6338 \mathrm{rad} / \mathrm{s}$.

\section{B. Periode Rolling}

Ketinggian cairan yang digunakan pada penelitian diantaranya adalah sebesar $10 \%, 30 \%, 50 \%$ dan $80 \%$.

Tabel 3.

Ketinggian cairan untuk analisis sloshing

\begin{tabular}{cc}
\hline \hline Ketinggian & Nilai (m) \\
\hline $10 \%$ & 1.065 \\
$30 \%$ & 3.195 \\
$50 \%$ & 5.325 \\
$80 \%$ & 8.520 \\
\hline \hline
\end{tabular}

\section{Jarak Keel to Metacenter}

Jarak KM diperlu didapatkan untun dapat mendefinisikan gerakan rolling yang terjadi

$$
K M=K G+G M
$$

$K M$ adalah jarak titik keel ke metacenter kapal, $K G$ adalah jarak titik keel ke gravitasi kapal, sedangkan $G M$ adalah jarak titik gravitasi muatan terhadap keel. GM didapatkan dengan menggunakan pendekatan yang ditulis pada common structural rules yaitu sebesar 0.4B.

\section{Gerakan rolling pada User Defined Function}

Gerakan rolling yang didefinisikan sebagai gerakan sinusoidal. Pergerakan dari tangki diturunkan dengan persamaan posisi untuk menjadi kecepatan.

$$
\theta_{\text {roll }}=\theta_{a} \sin (\omega t)
$$

Tabel 4.

Perhitungan jarak KM untuk gerakan rolling

\begin{tabular}{cccc}
\hline \hline $\begin{array}{c}\text { Ketinggian } \\
\text { cairan }\end{array}$ & KG $(\mathrm{m})$ & GM $(\mathrm{m})$ & KM $(\mathrm{m})$ \\
\hline $10 \%$ & 0.5425 & 6.648 & 7.1905 \\
$30 \%$ & 1.6277 & 6.648 & 8.2757 \\
$50 \%$ & 2.6967 & 6.648 & 9.3447 \\
$80 \%$ & 4.2990 & 6.648 & 10.947 \\
\hline \hline
\end{tabular}

$\theta_{\text {roll }}$ adalah posisi dari tangki, $\theta_{a}$ amplitudo dari rolling, $\omega$ adalah kecepatan angular dari rolling sedangkan $t$ adalah waktu tertentu. Persamaan (2) diturunkan terhadap waktu sehingga didapatkan persamaan pergerakan rolling.

$$
\omega_{\text {roll }}=\theta_{a}(\omega) \cos (\omega t)
$$

$\omega_{\text {roll }}$ adalah fungsi kecepatan osilasi dari rolling. Persamaan ini ditulis dalam UDF untuk dapat didefinisikan pergerakan rolling yang terjadi.

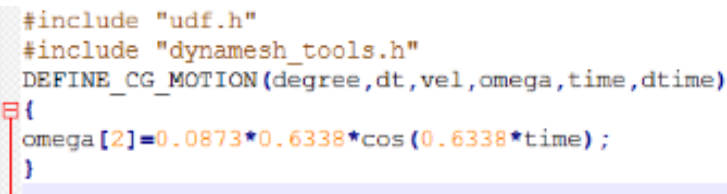

Gambar 6. Penulisan fungsi gerakan rolling pada User Defined Function

\section{E. Efek Sloshing}

Pengamatan dilakukan pada detik ke 9 pada masingmasing ketinggian cairan yang berada pada ruang muat.

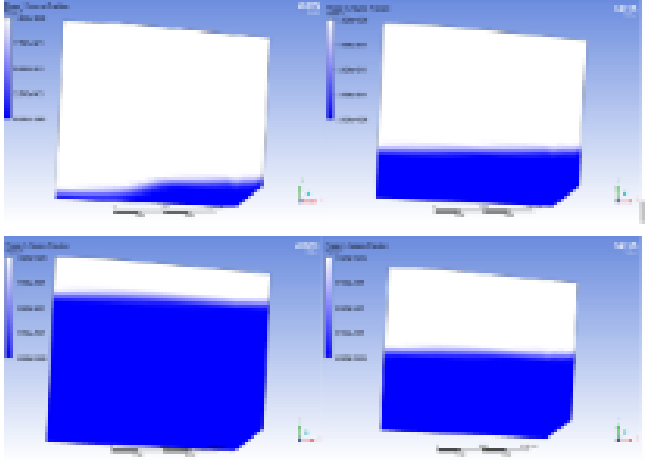

Gambar 7. Bentuk permukaan bebas untuk masing-masing ketinggian pada bagian starboard ruang muat.

Terjadi perbedaan yang signifikan antara puncak dan lembah gelombang yang terjadi ketika ketinggian cairan $10 \%$. Semakin tinggi ketinggian dari cairan, bentuk permukaan bebas yang terjadi relatif mendekati garis lurus terhadap sumbu x. Berbeda dengan ketinggian cairan 30\%, $50 \%$ dan $80 \%$ yang relatif lebih stabil dibandingkan dengan ketinggian $10 \%$.

\section{F. Analisis Beban Sloshing Ketinggian 10\% (Starboard)}

Karakteristik sloshing didapatkan dengan melihat perubahan pressure rata-rata yang terjadi pada sekat.

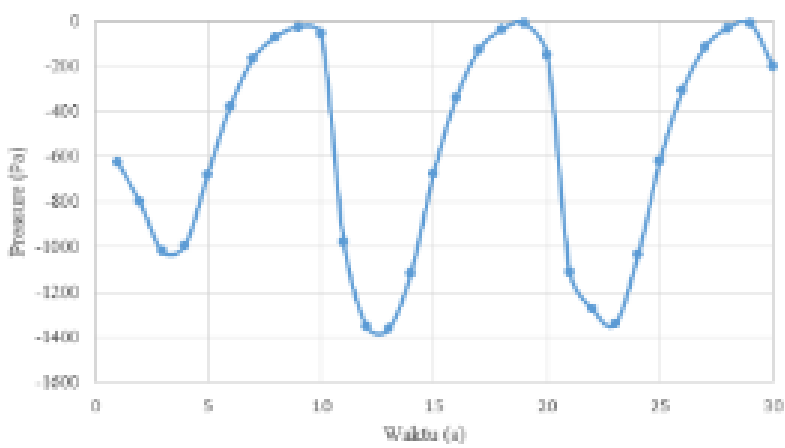

Gambar 8. Nilai pressure rata-rata yang didapatkan pada bagian starboard dari ruang muat saat ketinggian cairan sebesar $10 \%$.

Penentuan lama simulasi didasarkan pada intepretasi karakteristik sloshing untuk periode tertentu.

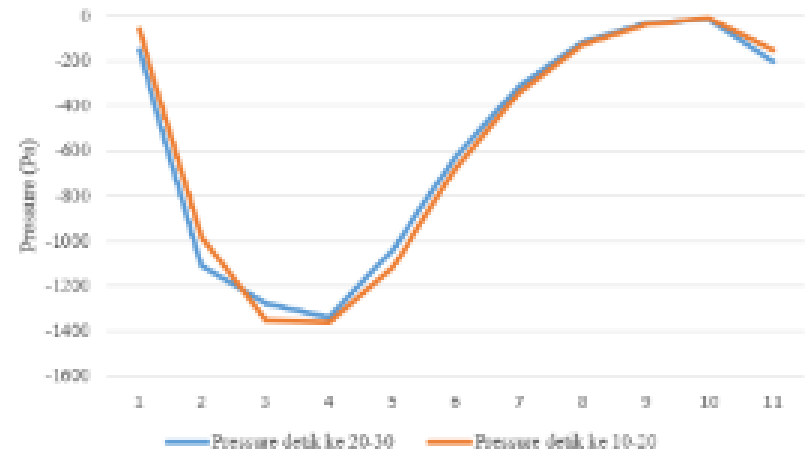

Gambar 9. Dasar penentuan lama simulasi sloshing 20 detik. Karakteristik periode ketiga memiliki nilai yang relatif sama dengan periode kedua.

\section{G. Analisis Beban Sloshing Ketinggian 10\% (Portside)}

Karakteristik sloshing didapatkan dengan melihat perubahan pressure rata-rata yang terjadi. 


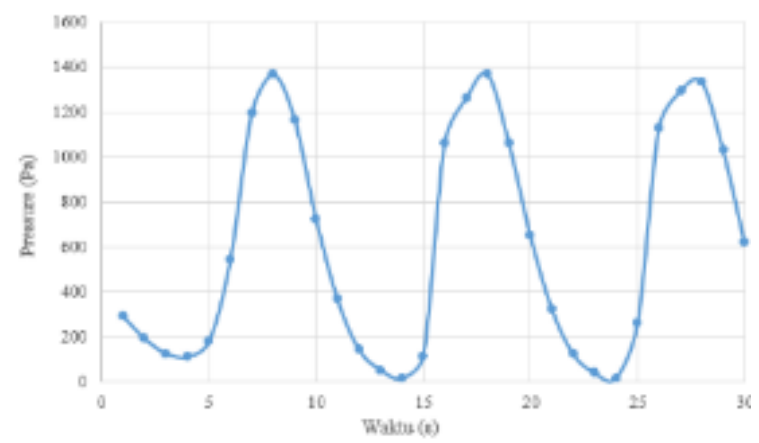

Gambar 10. Nilai pressure rata-rata yang didapatkan pada bagian portside dari ruang muat saat ketinggian cairan sebesar $10 \%$.

Penentuan lama simulasi didasarkan pada intepretasi karakteristik sloshing untuk periode tertentu.

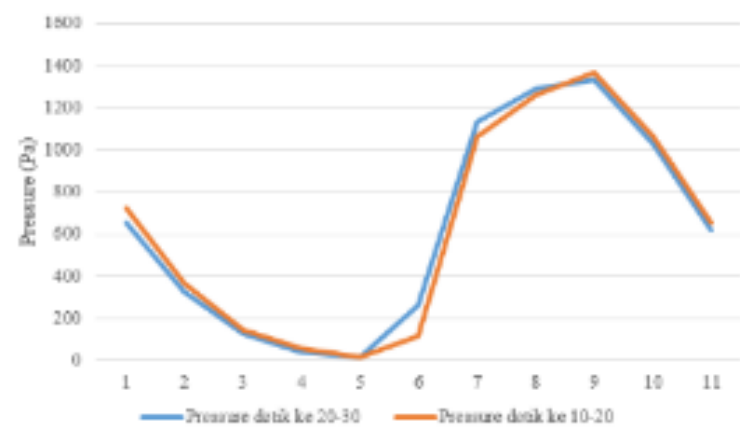

Gambar 11. Dasar penentuan lama simulasi sloshing 20 detik. Karakteristik periode ketiga memiliki nilai yang relatif sama dengan periode kedua.

\section{H. Analisis Beban Sloshing Ketinggian 30\% (Starboard)}

Karakteristik sloshing didapatkan dengan melihat perubahan pressure rata-rata yang terjadi pada sekat.

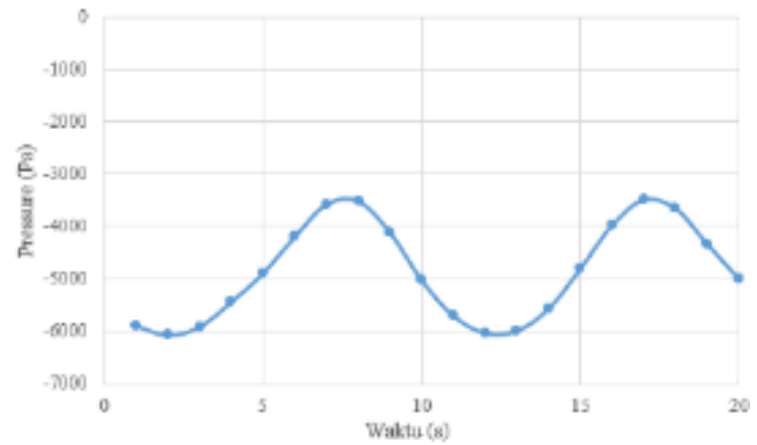

Gambar 12. Nilai pressure rata-rata yang didapatkan pada bagian starboard dari ruang muat saat ketinggian cairan sebesar $30 \%$.

\section{Analisis Beban Sloshing Ketinggian 30\% (Portside)}

Karakteristik sloshing didapatkan dengan melihat perubahan pressure rata-rata yang terjadi pada sekat.

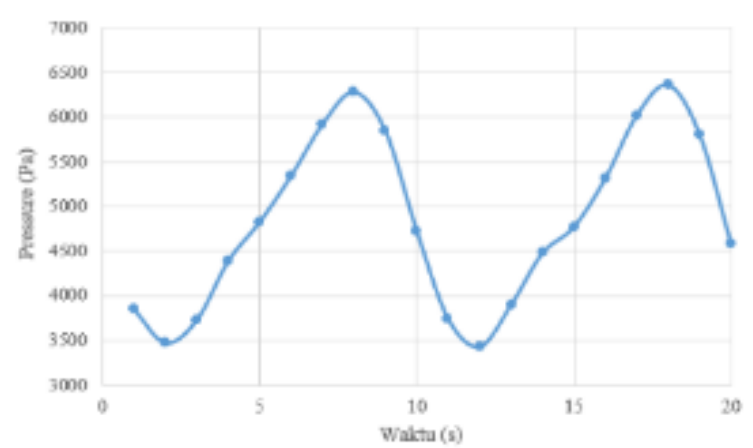

Gambar 13. Nilai pressure rata-rata yang didapatkan pada bagian portside dari ruang muat saat ketinggian cairan sebesar $30 \%$.
J. Analisis Beban Sloshing Ketinggian 50\% (Starboard)

Karakteristik sloshing didapatkan dengan melihat perubahan pressure rata-rata yang terjadi pada sekat.

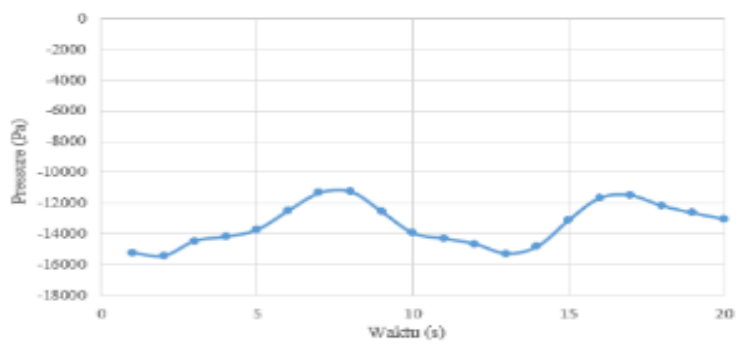

Gambar 14. Nilai pressure rata-rata yang didapatkan pada bagian starboard dari ruang muat saat ketinggian cairan sebesar $50 \%$.

\section{K. Analisis Beban Sloshing Ketinggian 50\% (Portside)}

Karakteristik sloshing didapatkan dengan melihat perubahan pressure rata-rata yang terjadi pada sekat.

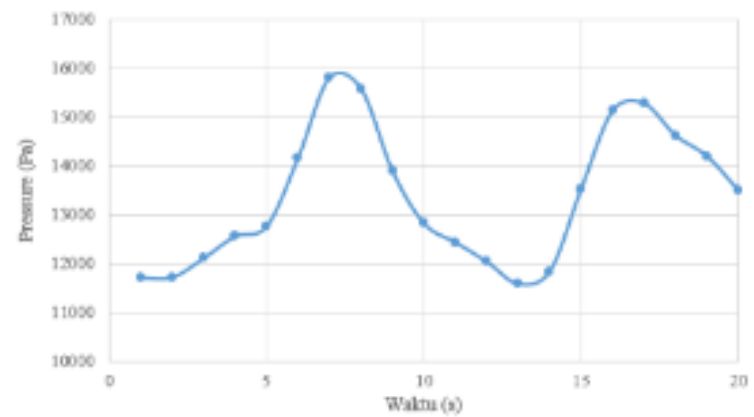

Gambar 15. Nilai pressure rata-rata yang didapatkan pada bagian portside dari ruang muat saat ketinggian cairan sebesar $50 \%$.

\section{Analisis Beban Sloshing Ketinggian $80 \%$ (Starboard)}

Karakteristik sloshing didapatkan dengan melihat perubahan pressure rata-rata yang terjadi pada sekat.

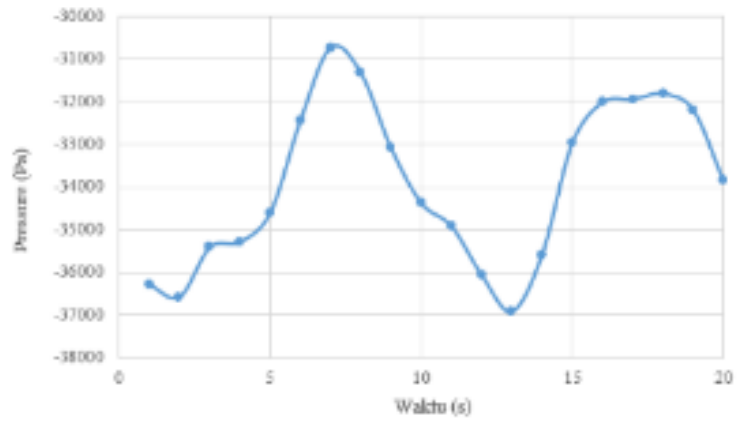

Gambar 16. Nilai pressure rata-rata yang didapatkan pada bagian starboard dari ruang muat saat ketinggian cairan sebesar $80 \%$.

M. Analisis Beban Sloshing Ketinggian $80 \%$ (Portside)

Karakteristik sloshing didapatkan dengan melihat perubahan pressure rata-rata yang terjadi pada sekat.

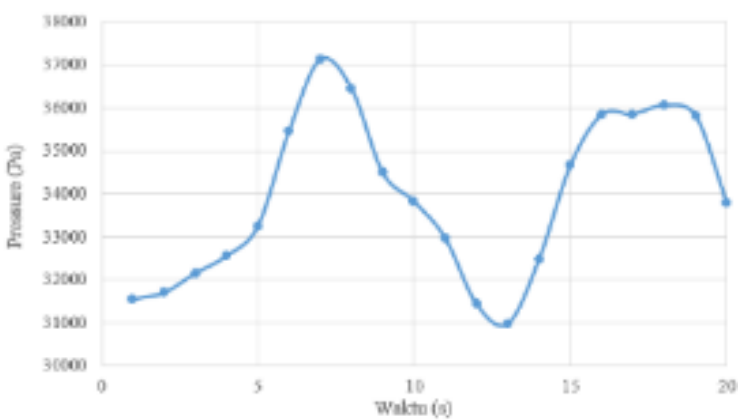

Gambar 16. Nilai pressure rata-rata yang didapatkan pada bagian portside dari ruang muat saat ketinggian cairan sebesar $80 \%$. 


\section{N. Perbandingan Pressure Masing-Masing Ketinggian}

Analisis dilanjutkan dengan membandingkan hasil pressure pada masing-masing ketinggian.

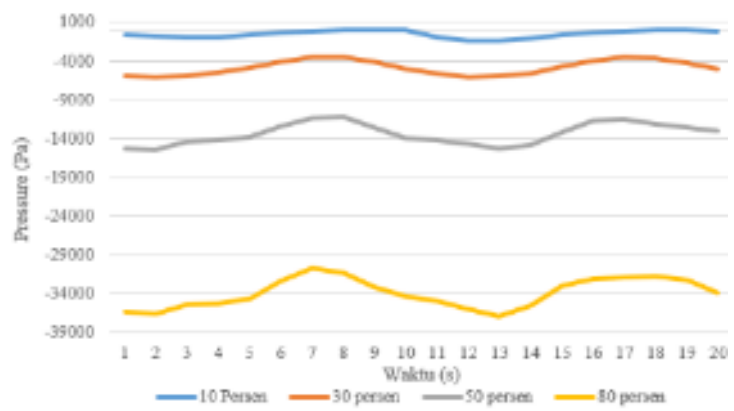

Gambar 17. Perbandingan pressure rata-rata untuk setiap ketinggian pada bagian starboard dari ruang muat.

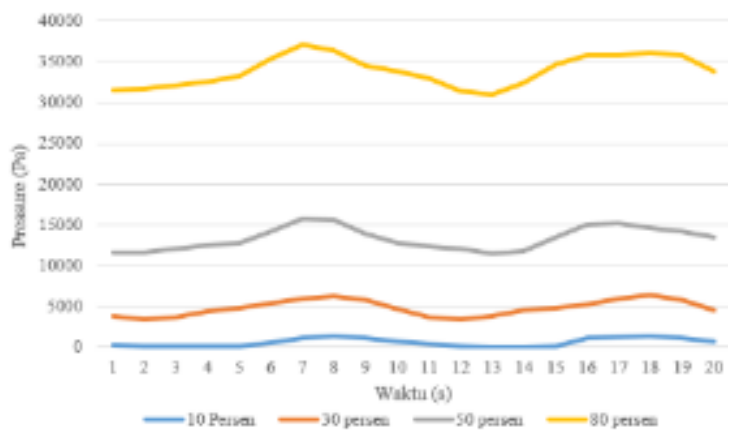

Gambar 18. Perbandingan pressure rata-rata untuk setiap ketinggian pada bagian portside dari ruang muat.

\section{O. Analisis Pembebanan}

Waktu terjadinya resultan terbesar digunakan sebagai acuan analisis struktur. Beban terbesar pada saat ketinggian $10 \%$ adalah pada detik ke 18 . Waktu terjadinya beban terbesar pada saat ketinggian cairan $30 \%$ adalah pada detik ke 8 , sedangkan untuk ketinggian $50 \%$ dan $80 \%$ beban terbesar yang berada pada domain sekat berada pada detik ke 7 .

\section{P. Snapshot Tangki Sebagai Dasar pembebanan}

Kondisi cairan pada tangki yang digunakan sebagai pembebanan dianalisis.

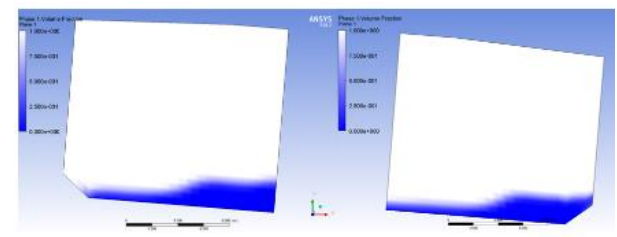

Gambar 19. Snapshot tangki ketinggian 10\% detik ke 17
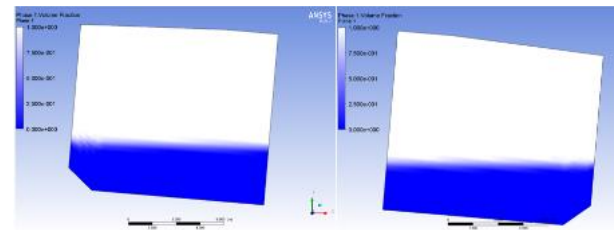

Gambar 20. Snapshot tangki ketinggian $30 \%$ detik ke 8
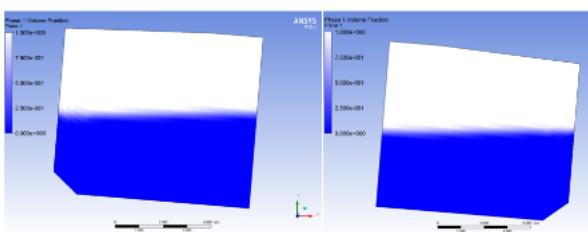

Gambar 21. Snapshot tangki ketinggian 50\% detik ke 7

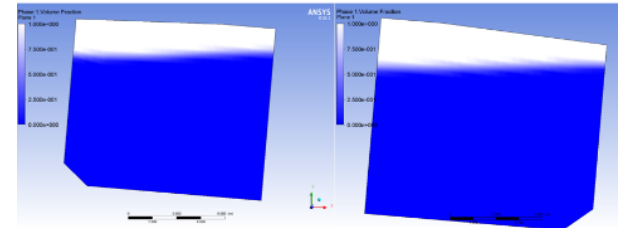

Gambar 22. Snapshot tangki ketinggian $80 \%$ detik ke 7

Bagian portside dari tangki berada pada kondisi maksimum karena kondisinya cairan pada bagian tersebut berada pada ketinggian maksimum, sedangkan kondisi bagian starboard berada pada kondisi minimum karena pada bagian tersebut cairan yang berada pada sekat memiliki ketinggian minimum.

\section{Q. Pembebanan Pada Struktur}

Beban pada struktur didapatkan dengan mengintegrasikan solution yang didapatkan dari hasil simulasi menggunakan computational fluid dynamics. Analisis dilakukan dengan menggunakan FSI (Fluid Structure Interaction) one way. Analisis ini digunakan untuk dapat menjelaskan perilaku dari struktur akibat beban yang dihasilkan oleh fluida.

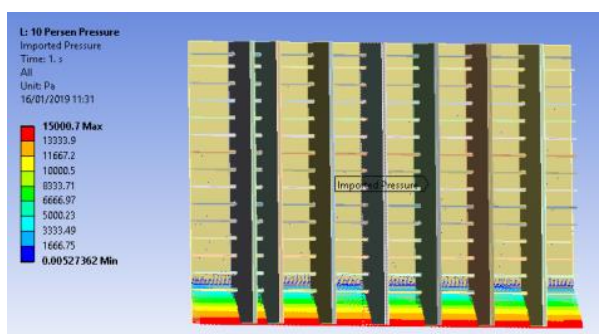

Gambar 23(a). Imported pressure bagian starboard untuk ketinggian $10 \%$

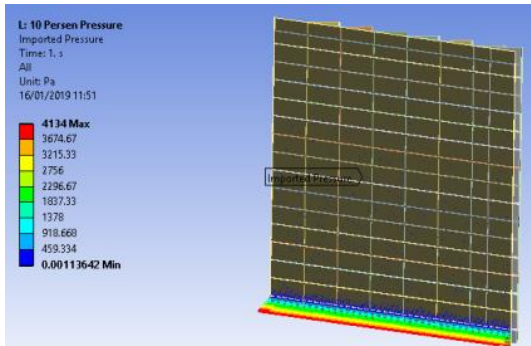

Gambar 23(b). Imported pressure bagian portside untuk ketinggian $10 \%$

Terdapat dua beban yang diinputkan pada analisis struktur, beban tersebut berada pada bagian starboard dan portside dari sekat. Hal ini dilakukan karena fluida yang berada pada ruang muat juga terdapat pada kedua sisi dari sekat tersebut.

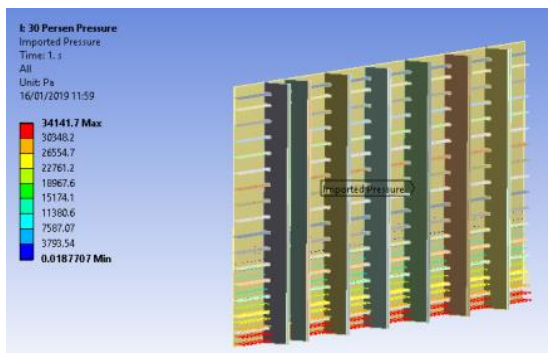

Gambar 24(a). Imported pressure bagian starboard untuk ketinggian 30\% 


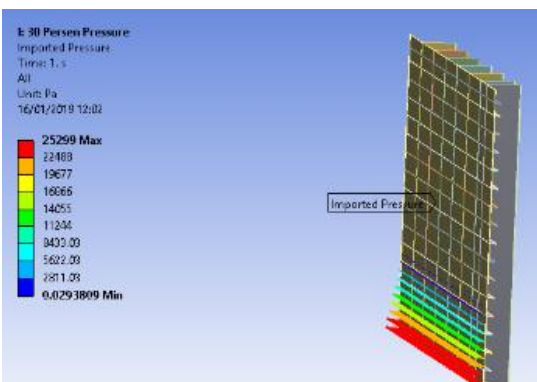

Gambar 24(b). Imported pressure bagian portside untuk ketinggian 30\%

Beban yang terjadi pada ketinggian $30 \%$ memiliki resultan yang lebih besar dibandingkan dengan pada saat ketinggian cairan $10 \%$.

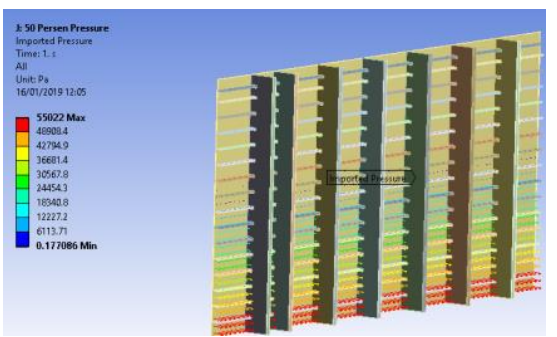

Gambar 25(a). Imported pressure bagian starboard untuk ketinggian 50\%

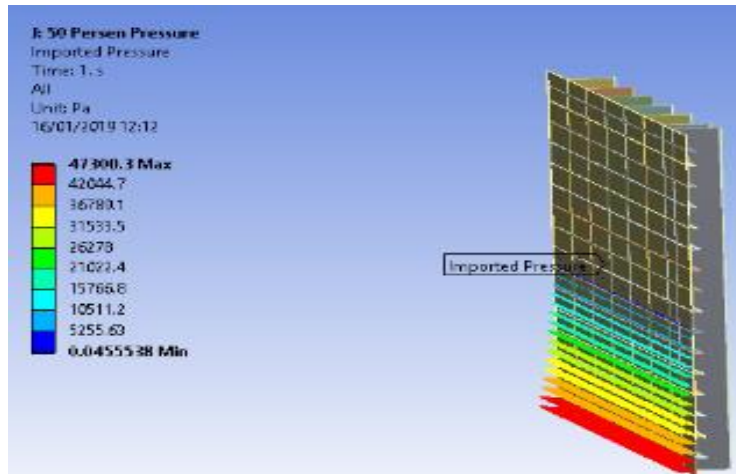

Gambar 25(a). Imported pressure bagian portside untuk ketinggian 50\%

Beban yang terjadi pada ketinggian 50\% memiliki resultan yang lebih besar dibandingkan dengan pada saat ketinggian cairan $30 \%$.

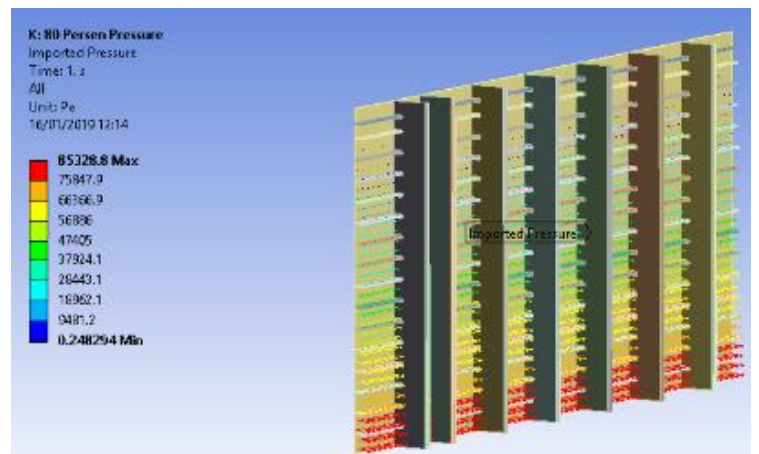

Gambar 26(a). Imported pressure bagian starboard untuk ketinggian $80 \%$

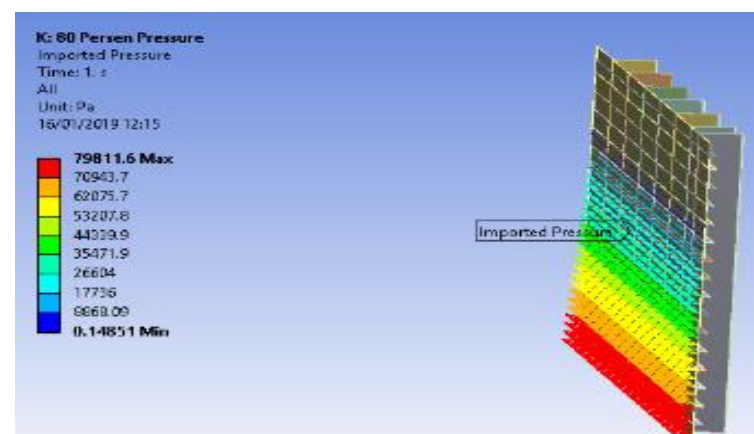

Gambar 26(b). Imported pressure bagian portside untuk ketinggian $80 \%$

Beban yang terjadi pada ketinggian $80 \%$ memiliki resultan yang lebih besar dibandingkan dengan pada saat ketinggian cairan $50 \%$.

Beban yang terjadi memiliki besar maksimal pada daerah dasar dari tangki, sedangkan beban tersebut berkurang seiring dengan bertambahnya ketinggian dari cairan. Pressure inilah yang digunakan sebagai pembebanan struktur bagian starboard dan portside dari ruang muat

\section{R. Hasil Analisis Struktur}

Hasil analisis struktur didapatkan setelah melakukan pembebanan dan penerapan kondisi batas pada struktur sekat memanjang kapal tanker. Analisis dilakukan pada tegangan von mises atau tegangan equivalent dan deformasi yang terjadi pada struktur. Hal ini dilakukan untuk dapat diketahui pengaruh sloshing terhadap tegangan dan deformasi yang terjadi.

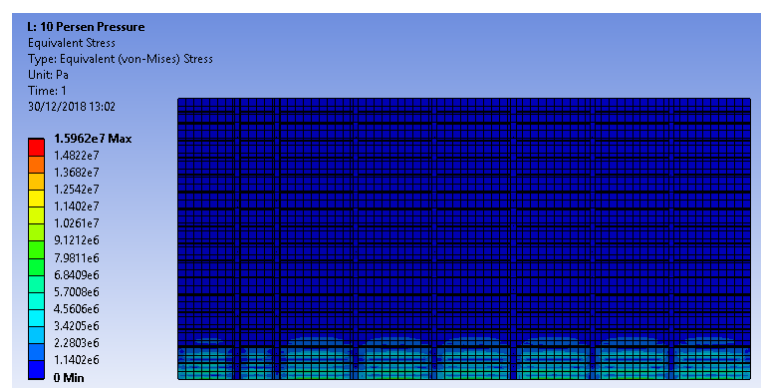

Gambar 27. Hasil tegangan von mises saat ketinggian cairan 10\%. Tegangan maksimal yang terjadi adalah sebesar $15.96 \mathrm{Mpa}$.

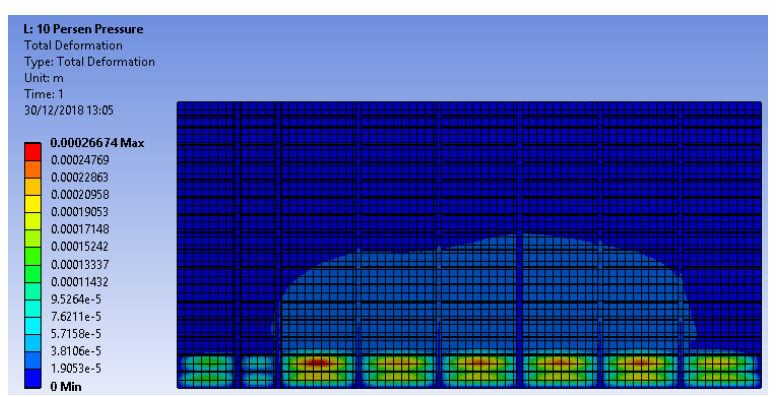

Gambar 28. Hasil deformasi saat ketinggian cairan 10\%. Deformasi maksimal yang terjadi adalah sebesar $0.266 \mathrm{~mm}$.

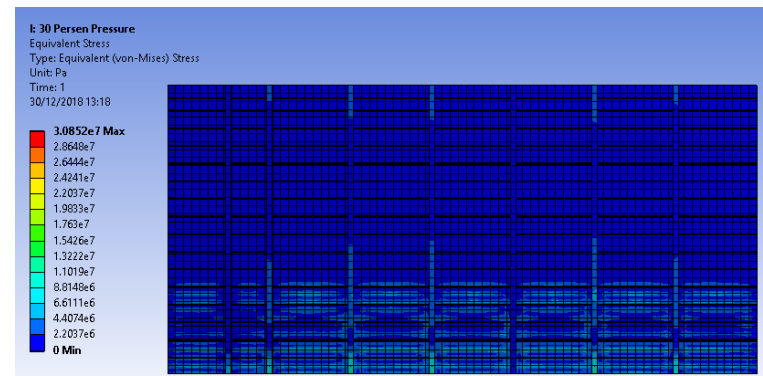

Gambar 29. Hasil tegangan von mises saat ketinggian cairan 30\%. Tegangan maksimal yang terjadi adalah sebesar $30.85 \mathrm{Mpa}$. 


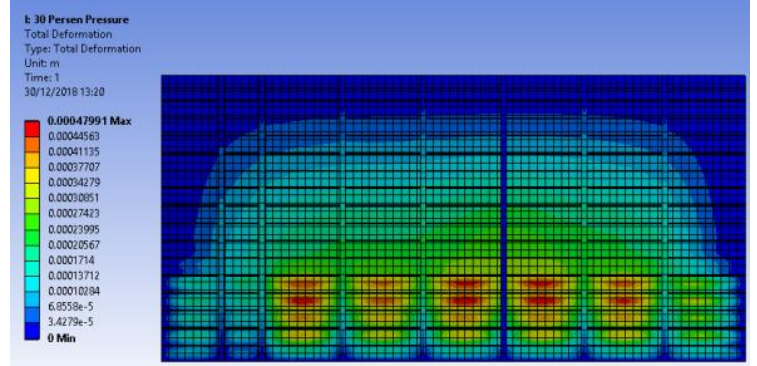

Gambar 30. Hasil deformasi saat ketinggian cairan 30\%. Deformasi maksimal yang terjadi adalah sebesar $0.479 \mathrm{~mm}$.

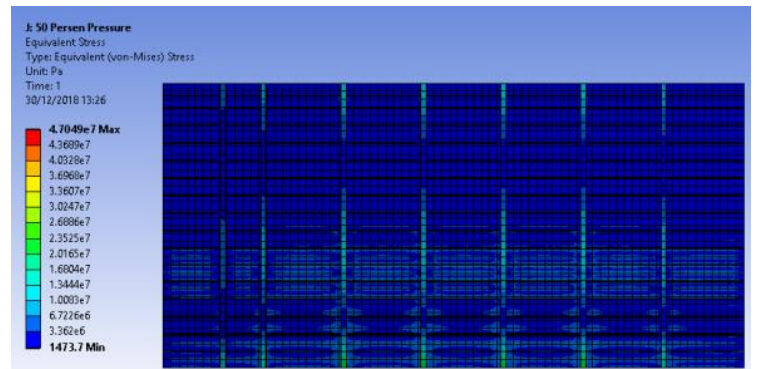

Gambar 31. Hasil tegangan von mises saat ketinggian cairan 50\%. Tegangan maksimal yang terjadi adalah sebesar 47.05 Mpa.

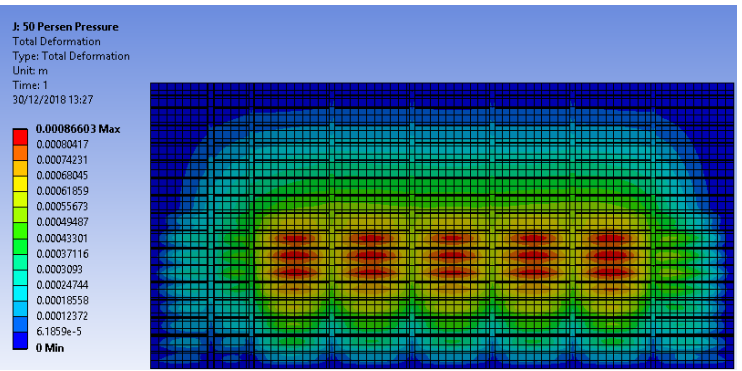

Gambar 32. Hasil deformasi saat ketinggian cairan 50\%. Deformasi maksimal yang terjadi adalah sebesar $0.866 \mathrm{~mm}$.

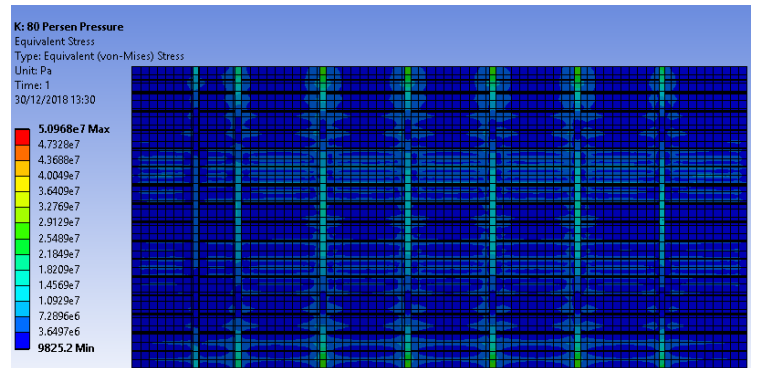

Gambar 33. Hasil tegangan von mises saat ketinggian cairan $80 \%$. Tegangan maksimal yang terjadi adalah sebesar $50.97 \mathrm{Mpa}$.

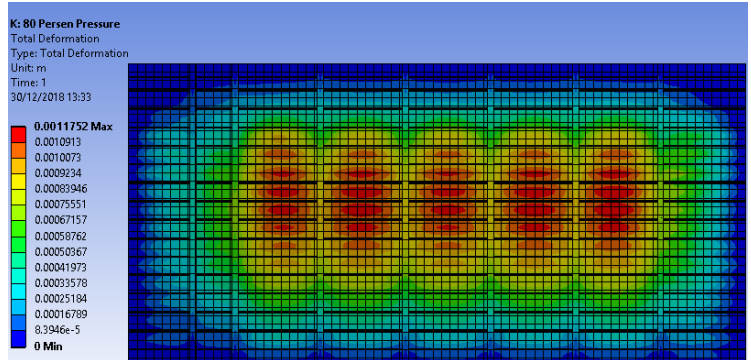

Gambar 34. Hasil deformasi saat ketinggian cairan 80\%. Deformasi maksimal yang terjadi adalah sebesar $1.17 \mathrm{~mm}$.

Tabel 5.

Perbandingan tegangan dan deformasi saat ketinggian cairan tertentu

\begin{tabular}{ccccc}
\hline \hline $\begin{array}{c}\text { Ketinggian } \\
\text { cairan }\end{array}$ & $\begin{array}{c}\text { Tegangan } \\
\text { maksimum } \\
(\mathbf{M p a})\end{array}$ & $\begin{array}{c}\text { Deformasi } \\
\text { maksimum } \\
(\mathbf{m m})\end{array}$ & $\begin{array}{c}\text { Lokasi } \\
\text { tegangan }\end{array}$ & $\begin{array}{c}\text { Lokasi } \\
\text { deformasi }\end{array}$ \\
\hline $10 \%$ & 15.962 & 0.26674 & pelat & pelat \\
$30 \%$ & 30.852 & 0.47991 & transverse & pelat
\end{tabular}

\begin{tabular}{llccc}
$50 \%$ & 47.049 & 0.86603 & transverse & pelat \\
$80 \%$ & 50.968 & 1.1752 & transverse & pelat \\
\hline \hline
\end{tabular}

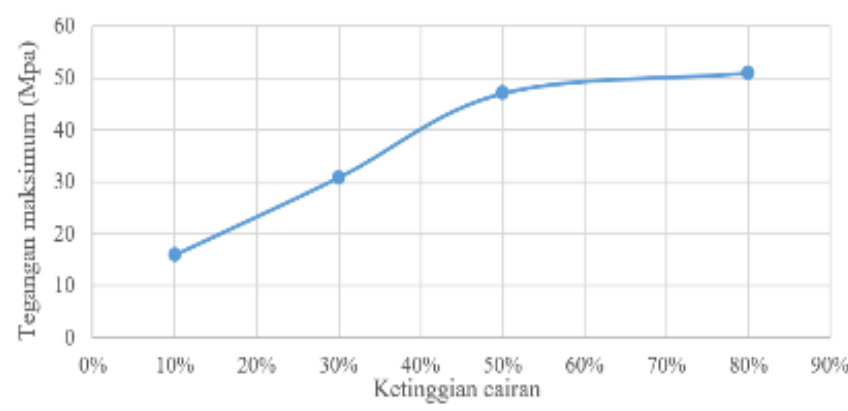

Gambar 35. Perbandingan tegangan yang didapatkan untuk masing-masing ketinggian cairan. Terjadi lonjakan tegangan yang cukup signifikan saat ketinggian rendah yaitu mencapai $93.28 \%$ saat ketinggian cairan dari $10 \%$ ke $30 \%$.

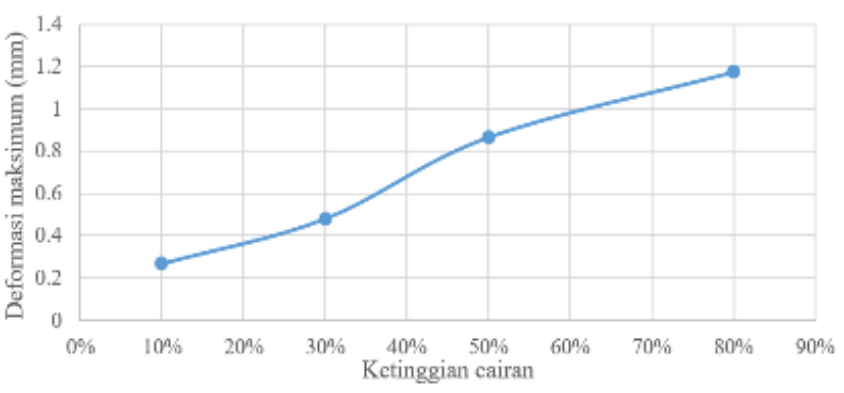

Gambar 36. Perbandingan deformasi yang didapatkan untuk masing-masing ketinggian cairan. Semakin tinggi ketinggian cairan, deformasi yang dihasilkan semakin besar.

\section{KESIMPULAN}

1. Efek permukaan bebas dipengaruhi oleh ketinggian dari cairan. Semakin kecil ketinggian dari cairan, maka efek permukaan bebas yang dihasilkan semakin besar.

2. Besar beban sloshing bervariasi berdasarkan ketinggian cairan. Semakin kecil ketinggian dari cairan maka beban sloshing yang dihasilkan juga semakin kecil. Beban sloshing terbesar pada saat kondisi ketinggian $80 \%$ yaitu hingga mencapai 6380 Pascal, tetapi kenaikan yang terjadi pada saat beban $80 \%$ tidak signifikan.

3. Besarnya fluktuasi beban sloshing dipengaruhi oleh ketinggian dari cairan. Semakin tinggi cairan yang terdapat pada ruang muat maka fluktuasi yang terjadi pada beban tersebut juga semakin besar.

4. Terdapat kenaikan tegangan yang cukup signifikan saat kondisi ruang muat terisi dengan ketinggian rendah. Saat ruang muat terisi dari $10 \%$ ke $30 \%$ kenaikan tegangan yang terjadi hingga mencapai $93.28 \%$.

\section{DAFTAR PUSTAKA}

[1] R. Bass, "Dynamic slosh induced loads on liquid cargo tank bulkheads.," New York, 1975.

[2] IACS, Common Structural Rules for Double Hull Oil Tankers. Italy: RINA, 2014

[3] N. H. Abramson, "The dynamic behavior of liquids in moving containers, with applications to space vehicle technology," Washington D.C, Jan. 1966.

[4] R. Romadhoni, "Analisa olah gerak kspsl di gelombang reguler pada kapal tipe axe bow," Kapal J. Ilmu Pengetah. dan Teknol. Kelaut., vol. 13, no. 2, pp. 61-68, Oct. 2016.

[5] H. R. Darmawan, "Analisis fatigue life pada struktur sekat tangk ruang muat kapal LNG \&quot;LNGC DISHA\&quot; akibat beban sloshing terhadap gerakan pitching menggunakan Finite Element Method (FEM),"Surabaya, 2015

[6] G. Popov, "Dynamics of liquid sloshing in road containers," 
Concordia University, 1991.

[7] K. A. Ashar and A. Sulisetyono, "Studi gerakan sloshing terhadap tangki kotak (rectangular tank) dengan dan tanpa pelat memanjang (baffle) akibat gerakan rolling kapal dengan metode Computational Fluid Dynamics (CFD)," J. Tek. ITS, vol. 2, no. 1, pp. G106-G111, Mar. 2013.
[8] S. H. Ardianus and D. S. Sujiatanti, "Analisa kekuatan konstruksi sekat melintang kapal tanker dengan metode elemen hingga," J. Tek. ITS, vol. 6, no. 2, 2017.

[9] R. Burow, "Identification of liquid sloshing dynamics by CFD analysis on board of a spin stabilized satellite," Universität Bremen, 2016. 